ZOOLOGIA 27 (4): 649-659, August, 2010

doi: $10.1590 /$ S1984-46702010000400013

\title{
On the Neotropical spider genus Eurymorion (Araneae: Linyphiidae)
}

\author{
Everton Nei Lopes Rodrigues ${ }^{1,2} \&$ Ricardo Ott ${ }^{2}$
}

\author{
${ }^{1}$ Corresponding author. Programa de Pós-Graduação em Biologia Animal, Departamento de Zoologia, Instituto de \\ Biociências, Universidade Federal do Rio Grande do Sul. Avenida Bento Gonçalves 9500, Bloco IV, Prédio 43435, \\ 91501-970 Porto Alegre, RS, Brazil.E-mail: enlrodrigues@yahoo.com.br \\ ${ }^{2}$ Museu de Ciências Naturais, Fundação Zoobotânica do Rio Grande do Sul. Rua Dr Salvador França 1427, \\ 90690-000 Porto Alegre, RS, Brazil.E-mail: rott@fzb.rs.gov.br
}

\begin{abstract}
The Neotropical genus of spider Eurymorion includes, until now, only two species: E. insigne (Millidge, 1991) and E. nobile (Millidge, 1991); both known only by males from the states of Rio de Janeiro and São Paulo (Southeastern Brazil), respectively. The genus is diagnosed mainly by the male palp with a small paracymbium and by the prolonged and medially constricted abdomen. In this paper we describe and illustrate three news species: E. triunfo sp. nov. based on male and female specimens from the states of Paraná, Santa Catarina and Rio Grande do Sul (Brazil) and La Paz (Bolivia), male palp has a rounded lamella characteristica with less projected tip and less developed base of the frontal cheliceral spiniform process, females have long spermatic ducts following the course of the lateral borders of genital opening; E. murici sp. nov. based on a male and a female from the state of Alagoas (Brazil), male palp has a striated border lamella characteristica with less projected tip, subtegulum more than half the length of the cymbium, tegular duct forming a non sinuous curve and large frontal cheliceral spiniform process, female epigynum atrium with rounded lateral borders, less developed dorsal plate and separated spermathecae; and E. mourai sp. nov. based on a male from Rio Grande do Sul (Brazil), male palp with less prominent lamella characteristica distal end, embolic division with only one distal projection, frontal cheliceral spiniform process larger and with slightly bifurcated tip. In addition, new illustrations based on the type material of the E. insigne and E. nobile are provided and the female of E. nobile is described and illustrated for the first time.
\end{abstract}

KEY WORDS. Bolivia; Brazil; Neotropical; new records; spider taxonomy.

Linyphiidae is the second species richest family in the order Araneae (Platnick 2009). Among the know linyphiids, figures the Neotropical Eurymorion Platnick, 1993, including the type species E. insigne (Millidge, 1991), from the state of Rio de Janeiro, and E. nobile (Millidge, 1991), from the state of São Paulo (Brazil). Both species are currently known only by males. The genus is characterized by the male palp with a very small paracymbium, a complex embolic division, a prolonged and medially constricted abdomen and a strong, anteriorly pointed boss at the chelicerae (Millidge 1991).

In this work, new illustrations based on the type specimens of Eurymorion insigne and E. nobile are presented and the female of $E$. nobile is described for the first time. The somatic morphology is also illustrated as a complement to MiLLIDGE's (1991) detailed description. Three new species are described: one species represented by males and females from the states of Paraná, Santa Catarina and Rio Grande do Sul, Brazil, and La Paz, Bolivia; one species represented by males and females from the state of Alagoas, Brazil, and one species represented by a single male from the state of Rio Grande do Sul, Brazil.

\section{MATERIAL AND METHODS}

Specimens were deposited in the collections of the American Museum of Natural History, New York, USA (AMNH, curator N.I. Platnick); Instituto Butantan, São Paulo, São Paulo, Brazil (IBSP, I. Knysak) and Museu de Ciências Naturais, Fundação Zoobotânica do Rio Grande do Sul, Porto Alegre, Rio Grande do Sul, Brazil (MCN, E.H. Buckup). For illustrations, specimens were examined under a Leica ${ }^{\circledR}$ MZ9.5 equipped with a camera lucida. The trichobothrium position on metatarsus I was calculated following Miluidge (1980). The description style and terminology of palpal morphology follow MiLLidge (1991). The tibial spine formula follows RoвerTs (1987). The study of the reproductive structures of both male and female was performed by immersing the epigynum and the embolic division in lactic acid and/or clove oil for approximately 30 minutes until the internal structures could be perfectly visualized. Expansion of the palp was done by immersing the structure in $10 \% \mathrm{KOH}$ for approximately two hours, and subsequently transferring it to distilled water. Throughout the descriptions, mea- 
surements are expressed in millimeters. The scanning electron micrographs (SEM) were taken on a JEOL ${ }^{\circledR}$ JSM-5200 electronic microscope located at the Museu de Ciências Naturais, Fundação Zoobotânica do Rio Grande do Sul. Abbreviations: (AME) anterior median eyes, (ALE) anterior lateral eyes, (PLE) posterior lateral eyes and (PME) posterior median eyes; (Tm I) trichobothrium position on metatarsus I.

\section{TAXONOMY}

\section{Eurymorion triunfo sp. nov. \\ Figs 1-10, 32-50}

Types. Holotype male from Parque Copesul de Proteção Ambiental (currently Braskem), Triunfo, Rio Grande do Sul, Brazil, 29-30.IX.2003, R. Ott leg., deposited in MCN 35738. Paratypes: 2 females, same locality, date and collector as the holotype (MCN 46698); 6 females, same locality and collector as holotype, 05.II.2003 (MCN 35172); 1 female, same locality as holotype, 30.XI.2001, R. Ott et al. leg. (MCN 38292); 1 male, same locality as holotype, 18.IX.2006, R. Ott \& A. Barcellos leg. (MCN 42164); 1 male, same locality as holotype, 12.XI.2007, A. Barcellos \& L. Schmidt leg. (MCN 43637); 1 female, same locality as holotype, 17.III.2008, E.N.L. Rodrigues \& M.C. Pairet, Jr. leg. (MCN 43977); 2 females, same locality as holotype, 03.IV.2008, A. Barcellos leg. (MCN 44033); 3 females, same locality as holotype, 02.VI.2008, M.A.L. Marques leg. (MCN 44111); 1 female, Porto Alegre, Arroio do Salso, Serraria, 17.IX.2003, R. Ott \& I. Heydrich leg. (MCN 36194).

Diagnosis. The male palp of Eurymorion triunfo sp. nov. (Figs 1-2 and 33-37) resembles that of E. insigne (Figs 22-23; Millidge, 1991: figs 236-237), in having a relatively simple paracymbium, long and filiform embolus and suprategular apophysis with hooked distal portion, but differs in the more developed paracymbium and with the lamella characteristica round and less projected tip (Fig. 1) and frontal cheliceral spiniform process base less developed (Figs 32 and 38). Female epigynum with a subtriangular atrium bearing a large and deep transversal opening divided by a longitudinal sept of prolonged and projected base originating from dorsal plate (Figs 9 and 47); subtriangular ventral plate bearing two posterior lateral lobes very close to each other and over the ventral plate, spermathecae at anterior portion of atrium, long spermatic ducts following the course of the lateral borders of genital opening (Fig. 10).

Description. Male (MCN 357381). Total length 2.95. Carapace length 1.40 , width 0.72 , height 0.44 . Clypeus height 0.21 . Chelicerae length 0.50 , width 0.22 . Sternum length 0.60 , width 0.47 . Abdomen length 1.50 , width 0.65 , height 0.75 . Leg formula I/IV/II/III. Leg lengths (I/II/III/IV): femora 1.15/1.10/0.87/ 1.17; patellae 0.27/0.25/0.22/0.25; tibiae 1.05/0.92/0.60/0.97; metatarsi 1.15/1.07/0.65/1.07; tarsi 0.67/0.57/0.40/0.57; total 4.29/3.91/2.74/4.03. Palp (femora, patellae, tibiae, cymbium): 0.37/0.10/0.15/0.50. Position of Tm I 0.17. Metatarsi I-III with trichobothrium. Tibial spine formula: 2-2-2-2. Eye diameters and interdistances: AME 0.05, ALE 0.07, PME 0.05, PLE 0.06; AME-ALE 0.11, PME-PLE 0.07, AME-AME 0.05, PME-PME 0.13. Anterior eye row 0.43, posterior row 0.46. Eyes (Figs 3, 5 and 32) margined with black. Cephalothorax dorsum glabrous, much longer than wide, narrowed posteriorly; cephalothorax predominantly dark-brown with borders, ocular area and cephalic area (from PME to fovea) yellowish. Chelicerae yellow with sparse distal hairs and a small basal tubercle (Fig. 5), and a strong spiniform frontal process (Figs 32 and 38-39); posterior portion of chelicerae paturon with a set 6-7 small hairs arising from tubercular basis (Figs 39-41). Promargin with two teeth, one small, the other well developed and orange-brown in color. Distal retromargin with four minute teeth and a larger basal tooth. Endites yellowish, covered with dark-brown dots. Sternum yellowish with darkened borders and sparse setae covering (Figs 4 and 42). Coxae yellow with darkened distal borders. Coxae III smaller than others (Fig. 42). Legs (Figs 43-46) yellowish, segments with median and distal dark rings. Patellae with a strong dorsal spine each. Abdomen longer than wide, with a pronounced median constriction (Figs 3-5); dorsally darkbrown; with four non-pigmented medium-posterior areas bearing small white-perolized spots and two lateral pale stripes; venter with white-perolized spots forming a " $Y$ " extending from epigastric furrow to spinnerets. Anterior spinnerets yellowbrown, posterior spinnerets and anal tubercle brownish. Colulus well developed. Palp with filiform embolus and embolic membrane (Figs 34 and 37); tegulum with sinuous margin and light sinuous ducts; suprategular apophysis membranous distally; paracymbium subtriagular, with short and strong spines (Fig. 35); lamella characteristica striated (Figs 33 and 34).

Female (MCN 46698). Total length 2.57. Carapace length 1.07 , width 0.70 , height 0.40 . Clypeus height 0.11 . Chelicerae length 0.50 , width 0.25 . Sternum length 0.60 , width 0.47 . Abdomen length 1.50 , width 1.00 , height 0.97 . Leg formula I/ IV/II/III. Leg lengths (I/II/III/IV): femora 1.00/0.95/0.70/1.02; patellae $0.27 / 0.27 / 0.22 / 0.25$; tibiae $0.87 / 0.80 / 0.55 / 0.80$; metatarsi 0.92/0.87/0.62/0.92; tarsi 0.57/0.55/0.42/0.50; total 3.63/ 3.44/2.51/3.49. Palp (femora, patellae, tibiae, tarsi): 0.25/0.12/ $0.25 / 0.35$. Position of Tm I 0.14. Metatarsi I-III with trichobothrium. Tibial spine formula: 2-2-2-2. Eye diameters and interdistances: AME 0.05, ALE 0.06, PME 0.08, PLE 0.07; AME-ALE 0.08, PME-PLE 0.03, AME-AME 0.03, PME-PME 0.06. Anterior eye row 0.40 , posterior row 0.42 . Eyes margined with black, primarily PME (Figs 6 and 8). Carapace much longer than wide; dark-brown with black dots; margins, ocular area and median cephalic area from PME to the fovea yellow. Chelicerae yellowish, with some sparse distal setae and without tubercle. Promargin with five dark-brown teeth, median teeth well developed. Retromargin with five minute teeth. Endites yellow with dark-brown dots. Sternum yellow with darkened borders, longer than wide (Fig. 7). Coxae yellowish, distal border darkened. Legs yellow, all segments with median and 

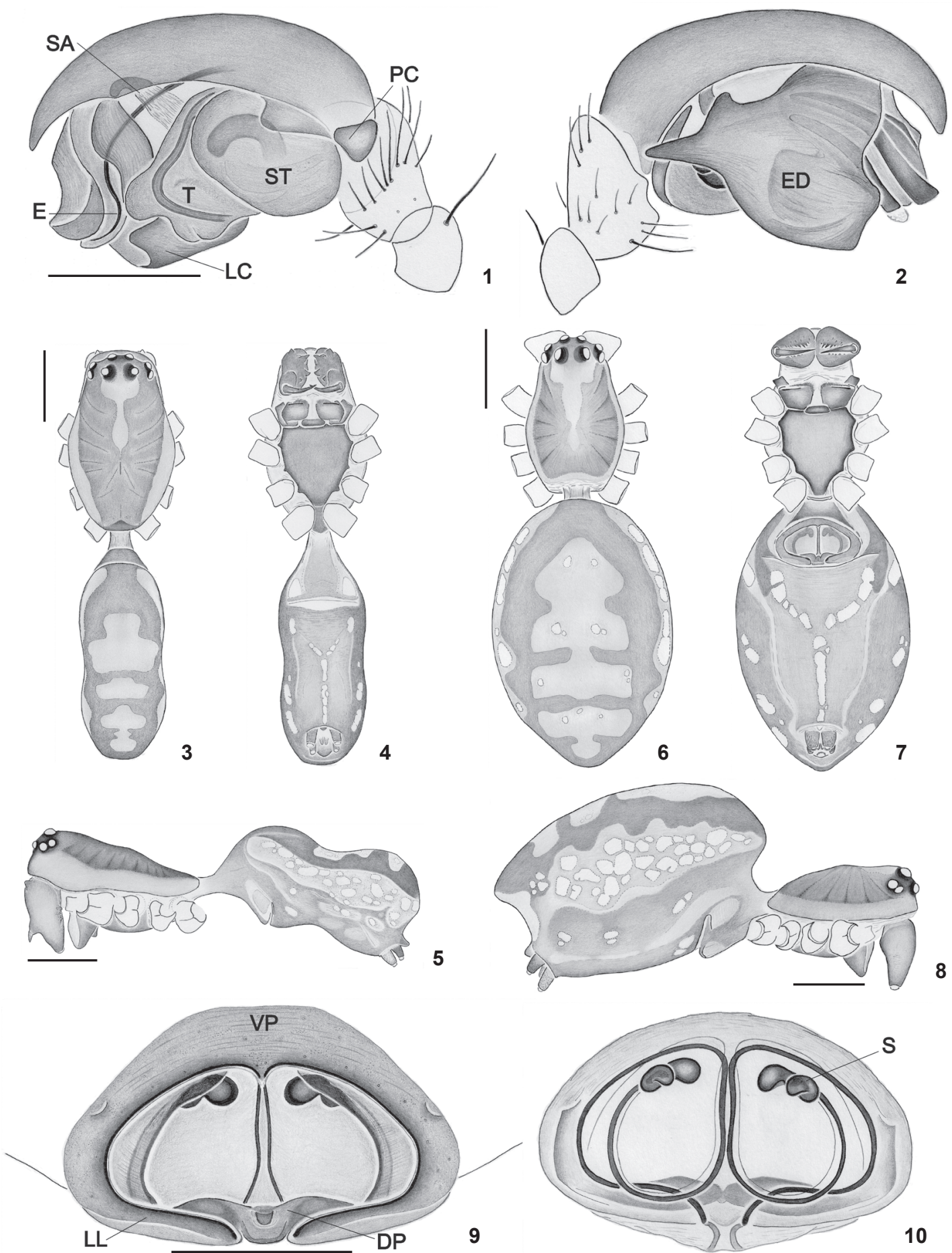

Figures 1-10. Eurymorion triunfo sp. nov.: (1-2) Male palpus: (1) ectal view, (2) mesal view; (3-5) male habitus: (3) dorsal view, (4) ventral view, (5) lateral view; (6-8) female habitus: (6) dorsal view, (7) ventral view, (8) lateral view; (9-10) female epygine: (9) ventral view, (10) dorsal view, cleared. (DP) Dorsal plate, (E) embolus, (ED) embolic division, (LC) lamella characteristica, (LL) lateral lobe, (PC) paracymbium, (SA) suprategular apophysis, (S) spermathecae, (ST) subtegulum, (T) tegulum, (VP) ventral plate. Scale lines: $(1,2,9-10)$ 0,25 mm, (38) $0,5 \mathrm{~mm}$. 
distal dark-brown rings. Patellae with a strong dorsal spine each. Abdomen oval, longer than wide, without median constriction, prolonging after spinnerets; dorsally dark-brown with median area not pigmented and two lateral pale stripes with small white-perolized spots; venter as in male (Fig. 7). Anterior spinnerets (Fig. 48) brownish, posterior spinnerets and anal tubercle dark-brown. Colulus well developed (Figs 48 and 49). Epigynum with spermathecae at anterior portion of atrium, spermatic ducts long, following the lateral borders of the atrial opening (Figs 9, 10 and 47).

Variation. Total length (10 males) 2.87-3.77 (Mean $=3.07$, $\left.\mathrm{SE}^{ \pm} 0.32\right)$; (10 females) 2.05-2.90 (2.58 ${ }^{ \pm 0.29)}$. The color pattern is quite variable from dark-brown to very pale specimens with remarkably white-perolized spots on abdomen. The male abdominal medial constriction varies from very conspicuous to almost absent.

Additional material examined. Bolivia, La Paz: La Paz, Rio Huarinilla, 1 female, 01.VIII.1993, H. Höfer leg. (MCN 24086). Brazil, Paraná: Foz do Iguaçú, Refúgio Biológico de Bela Vista, 3 females, 5 males, 17.III.1991, 09-11.XI.1991, A.B. Bonaldo leg. (MCN 20896, 20899, 21818, 21837), Santa Helena, Refúgio Biológico de Santa Helena, 3 females, 21.III.1991, 12-16.XI.1991, A.B. Bonaldo leg. (MCN 20929, 21670, 21778), Três Barras do Paraná, Córrego Três Barras, Rio Guarani, 2 females, 20-26.II.1993, A.B. Bonaldo leg. (MCN 23197), Capitão Leonidas Marques, Salto Caxias, Rio Iguaçú, 1 male, 2 females, 20-28.III.1993, A.B. Bonaldo leg. (MCN 23278, 23280, 23318); Santa Catarina: Porto Belo, Praia de Bombas, 1 female, 14.II.1990, A.D. Brescovit leg. (MCN 19493); Rio Grande do Sul: Canela, 2 females, 21.IX.1984, A.A. Lise leg. (MCN 12380), Campo Bom, 1 female, 19-20.V.1986, C.J. Becker leg. (MCN 15077), Santa Maria, 1 female, 08.IX.1985, L. Bertholdo leg. (MCN 15302), Santa Maria (Taquarixim), 1 female, 18.XI.1996, L. Indrusiak \& Monteiro leg. (MCN 33914), Novo Hamburgo, 1 female, 31.III.1986, C.J. Becker leg. (MCN 14547), Canoas, 2 females, 13.XII.1990, C.J. Becker leg. (MCN 20203), 1 female, 24.I.1991, M.A.L. Marques leg. (MCN 20455), Triunfo, Parque Copesul de Proteção Ambiental, 2 females, 21.IX.1989, E.H. Buckup leg. (MCN 18682), 1 female, 25.I.1990, A.B. Bonaldo leg. (MCN 19394), 1 female, 17.IX.1993, A.D. Brescovit leg. (MCN 23977), 1 female, 23.V.2000, E.H. Buckup leg. (MCN 32336), 1 female, 06.I.2005, R. Ott et al. leg. (MCN 38351), 1 male, 25.VIII.2005, R. Ott leg. (MCN 39993), 1 male, 14.VI.2006, R. Ott leg. (MCN 42039), 1 female, 12.XII.2006, A. Barcellos \& R. Ott leg. (MCN 42743), 1 male, 12.XII.2006, A. Barcellos \& R. Ott leg. (MCN 42744), 1 female, 15.III.2007, M.A.L. Marques leg. (MCN 43281), 1 female, 25.I.1990, A.D. Brescovit leg. (MCN 43341), 1 male, 2 females, 28.V.2007, E.N.L. Rodrigues \& M.A.L. Marques leg. (MCN 43350, 43352), 1 male, 12.XI.2007, A. Barcellos \& L. Schmidt leg. (MCN 43636), 1 male, 09.VII.2008, A. Barcellos et al. leg. (MCN 44161), 1 female, 11.XI.2008, A. Barcellos leg. (MCN 44997), Cachoeirinha, Estação Experimental do Arroz, IRGA, 1 female,
05.XI.2004, E.N.L. Rodrigues leg. (MCN 39118), Gravataí, Morungava, 1 female, 02.II.1992, A.D. Brescovit leg. (MCN 21983), Arroio dos Ratos, Fazenda Recanto da Figueira, 2 females, 01.VIII.1986, M.A.L. Marques leg. (MCN 15495), Palmares do Sul, Ilha Grande, Lagoa do Casamento $\left(30^{\circ} 20^{\prime} 10^{\prime \prime} \mathrm{S}\right.$ $\left.50^{\circ} 37^{\prime} 46^{\prime \prime} \mathrm{W}\right), 2$ females, 08-09.IV.2003, Equipe Probio leg. (MCN 35444, 35486), Tapes, Fazenda Guará, 1 female, 15.V.2003, R.S. de Araujo leg. (MCN 35924).

Distribution. Bolivia (La Paz) and Brazil (Paraná, Santa Catarina and Rio Grande do Sul) (Fig. 50).

Etymology. The specific name is a noun in apposition, taken from the type locality.

Natural history. The species can be collected from litter (through litter sieving), arboreal strata (by beating the higher vegetation strata or manually) and grasses and bushes (with a sweeping net). In Bolivia, the species was registered in altitudes between 1200-1500 $\mathrm{m}$ above sea level.

\section{Eurymorion murici sp. nov.}

Figs $11-19,30,50$

Types. Holotype male from Estação Ecológica de Murici

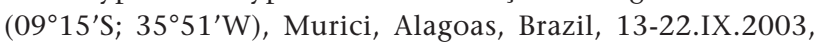
Equipe Biota leg., deposited in IBSP 154186. Paratype: female; same locality, date and collector as the holotype (IBSP 154187).

Diagnosis. The male palp of Eurymorion murici sp. nov. resembles that of E. nobile (Figs 24-25; MilLidge, 1991: figs 238239 ), in having the tegulum with smooth borders; suprategular apophysis with tip below cymbial margin and cymbium with distal portion hooked; it differs from E. nobile by the lamella characteristica with striated border and a less projected tip; subtegulum more than half the length of the cymbium and tegular duct forming a non sinuous curve (Fig. 11). The cheliceral frontal spiniform process is as large as in E. nobile, but with the base less developed, as in E. triunfo and E. insigne (Fig. 30). The female epigynum of $E$. murici sp. nov. differs from that of E. triunfo by the atrial opening with rounded lateral borders; the less developed dorsal plate, and the more separated spermathecae (Fig. 15).

Description. Male (IBSP 154186). Total length 2.95. Carapace length 1.40 , width 0.87 , height 0.52 . Clypeus height 0.22 . Chelicerae length 0.62 , width 0.27 . Sternum length 0.65 , width 0.57 . Abdomen length 1.45 , width 0.72 , height 0.67 . Leg formula I/IV/II/III. Leg lengths (I/II/III/IV): femora 1.30/1.22/0.92/ 1.32; patellae 0.27/0.27/0.25/0.27; tibiae 1.25/1.07/0.72/1.15; metatarsi 1.22/1.12/0.75/1.20; tarsi 0.67/0.62/0.42/0.60; total 4.71/4.30/3.06/4.54. Palp (femora, patellae, tibiae, cymbium): $0.44 / 0.12 / 0.22 / 0.55$. Position of Tm I 0.19. Metatarsi I-III with trichobothrium. Tibial spine formula: 2-2-2-2. Eye diameters and interdistances: AME 0.05, ALE 0.07, PME 0.06, PLE 0.07; AME-ALE 0.13, PME-PLE 0.08, AME-AME 0.05, PME-PME 0.12. Anterior eye row 0.50 , posterior row 0.51 . Ocular area darkbrown, eyes margined with black (Fig. 13). Carapace dark red- 

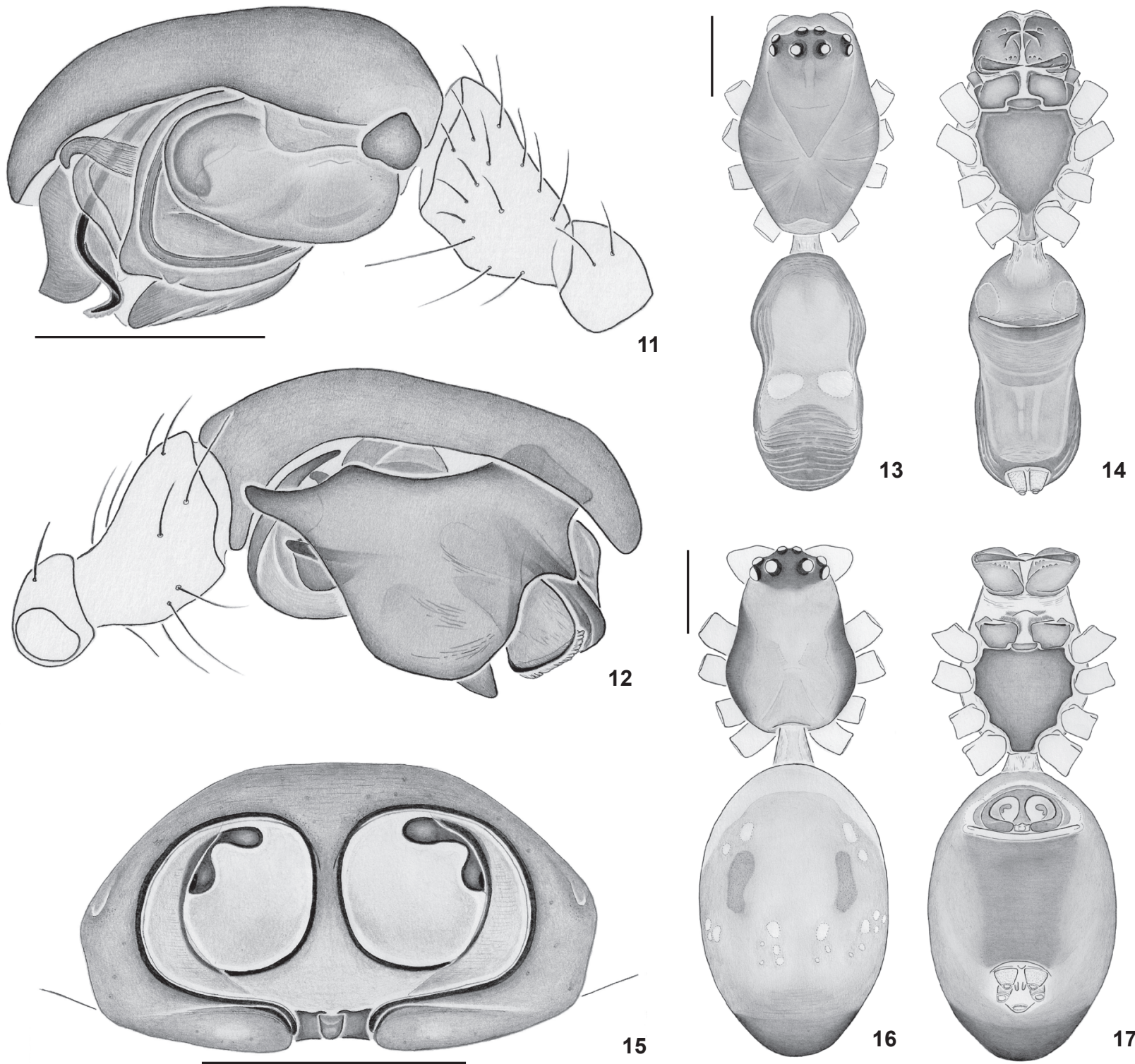

15

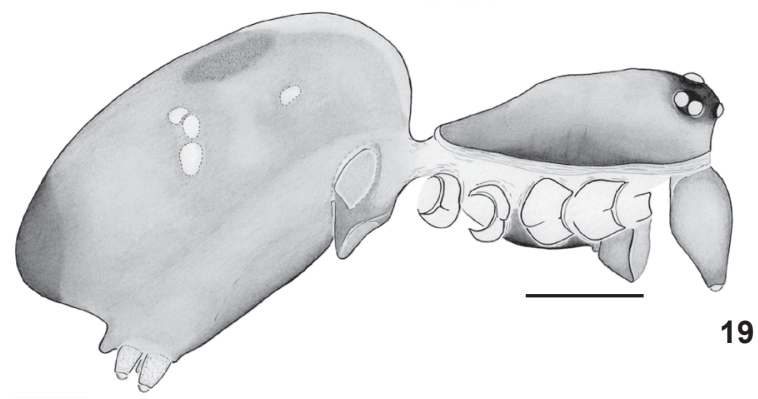

Figures 11-19. Eurymorion murici sp. nov.: (11-12) male palpus: (11) ectal view, (12) mesal view; (13-14, 18) male habitus: (13) dorsal view, (14) ventral view, (18) lateral view; $(16-17,19)$ female habitus: $(16)$ dorsal view, (17) ventral view, (19) lateral view; (15) female epygine: (15) ventral view. Scale lines: (11-12 and 15) 0,25 mm, (13-14, 16-19) 0,5 mm. 

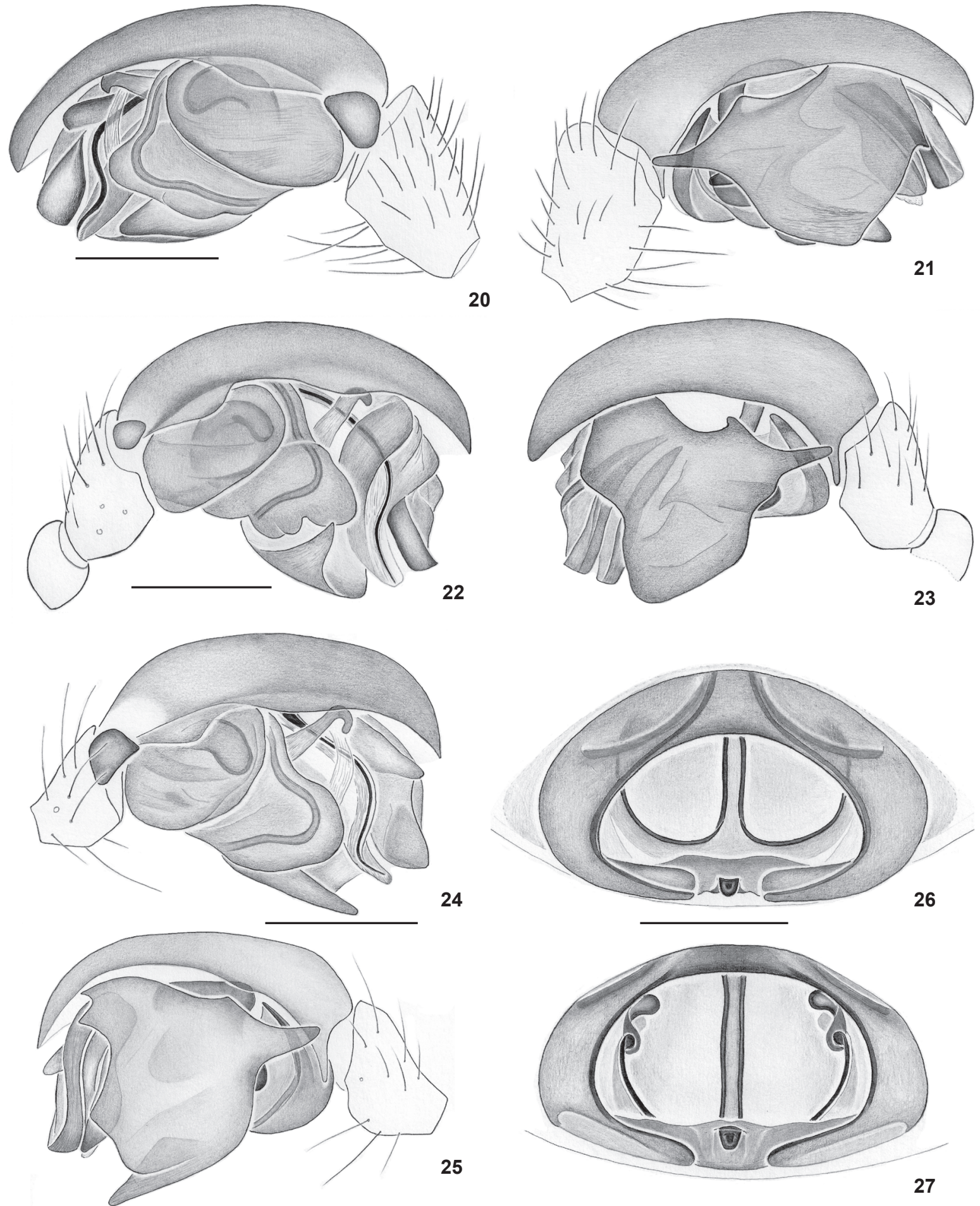

Figures 20-27. (20-21) Eurymorion mourai sp. nov.: (20-21) male palpus: (20) ectal view, (21) mesal view; (22-23) E. insigne: (22-23) male palpus: (22) ectal view, (23) mesal view; (24-27) E. nobile: (24-25) male palpus: (24) ectal view, (25) mesal view; (26-27) female epygine: (26) ventral view, (27) posterior view. Scale lines: 0,25 mm. 

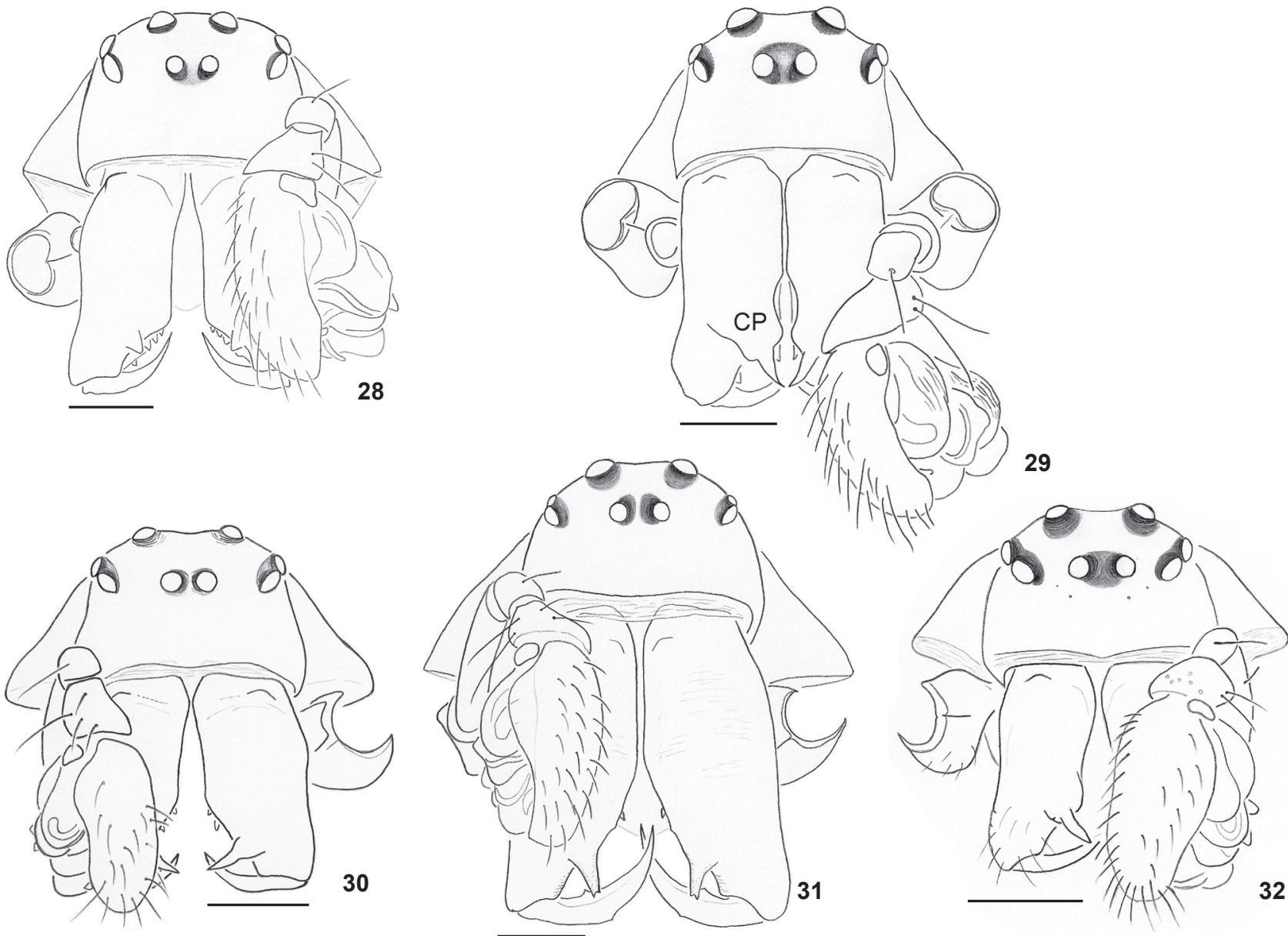

Figures 28-32. Cephalothorax, frontal view: (28) Eurymorion nobile; (29) E. insigne; (30) E. murici sp. nov.; (31) E. mourai sp. nov.; (32) E. triunfo sp. nov. (CP) Cheliceral process. Scale lines: $0,5 \mathrm{~mm}$.

brown with dark-brown dots, dorsally glabrous, longer than wide, narrowing posteriorly. Chelicerae dark red-brow with small basal tubercle; sparse distal setae and strong frontal spiniform process. Promargin with four minute teeth. Retromargin with two teeth. Endites (Fig. 14) yellow-brown. Sternum longer than wide, dark brown, with sparse setae cover. Coxae yellow-brown, III smaller than others. Legs yellowbrown. Patellae with strong dorsal spine. Abdomen longer than wide, with a strong median constriction (Fig. 18), dorsally dark brown with two umpigmented medial-posterior areas; remarkably striated at posterior end; venter dark brown. Spinnerets yellow-brown. Colulus well developed. Palp with long subtegulum; tegulum with a ventral projection (Fig. 11); embolic membrane slight and embolic division (sensu MiLlidge 1991) plate-like, covering the prolateral side of palp (Fig. 12).

Paratype female (IBSP 154187). Total length 3.10. Carapace length 1.12 , width 0.72 , height 0.44 . Clypeus height 0.11 . Chelicerae length 0.55 , width 0.25 . Sternum length 0.65 , width
0.57. Abdomen length 1.85 , width 1.12 , height 1.05 . Leg formula I/IV/II/III. Leg lengths (I/II/III/IV): femora 1.12/1.02/0.75/ 1.15; patellae $0.30 / 0.27 / 0.27 / 0.27$; tibiae $0.97 / 0.82 / 0.57 / 0.95$; metatarsi 0.92/0.89/0.67/0.95; tarsi 0.57/0.55/0.40/0.52; total 3.88/3.55/2.66/3.84. Palp (femora, patellae, tibiae, tarsi): 0.32/ $0.10 / 0.30 / 0.35$. Position of Tm I 0.17. Metatarsi I-III with trichobothrium. Tibial spine formula: 2-2-2-2. Eye diameters and interdistances: AME 0.05, ALE 0.08, PME 0.06, PLE 0.08; AME-ALE 0.08, PME-PLE 0.06, AME-AME 0.03, PME-PME 0.11. Anterior eye row 0.43 , posterior row 0.46. Ocular area darkened; eyes with dark margins, mainly the PME. Carapace yellow, glabrous, much longer than wide; laterals dark brown with black dots (Fig. 16). Chelicerae yellow, without tubercles, glabrous; promargin with five dark brown, well-developed teeth; retromargin with five minute teeth. Endites yellowish; labium whitish. Sternum (Fig. 17) dark red-brown, longer than wide. Legs yellow. Patellae with a strong dorsal spine each. Abdomen longer than wide, oval, prolonging over spinnerets, without 

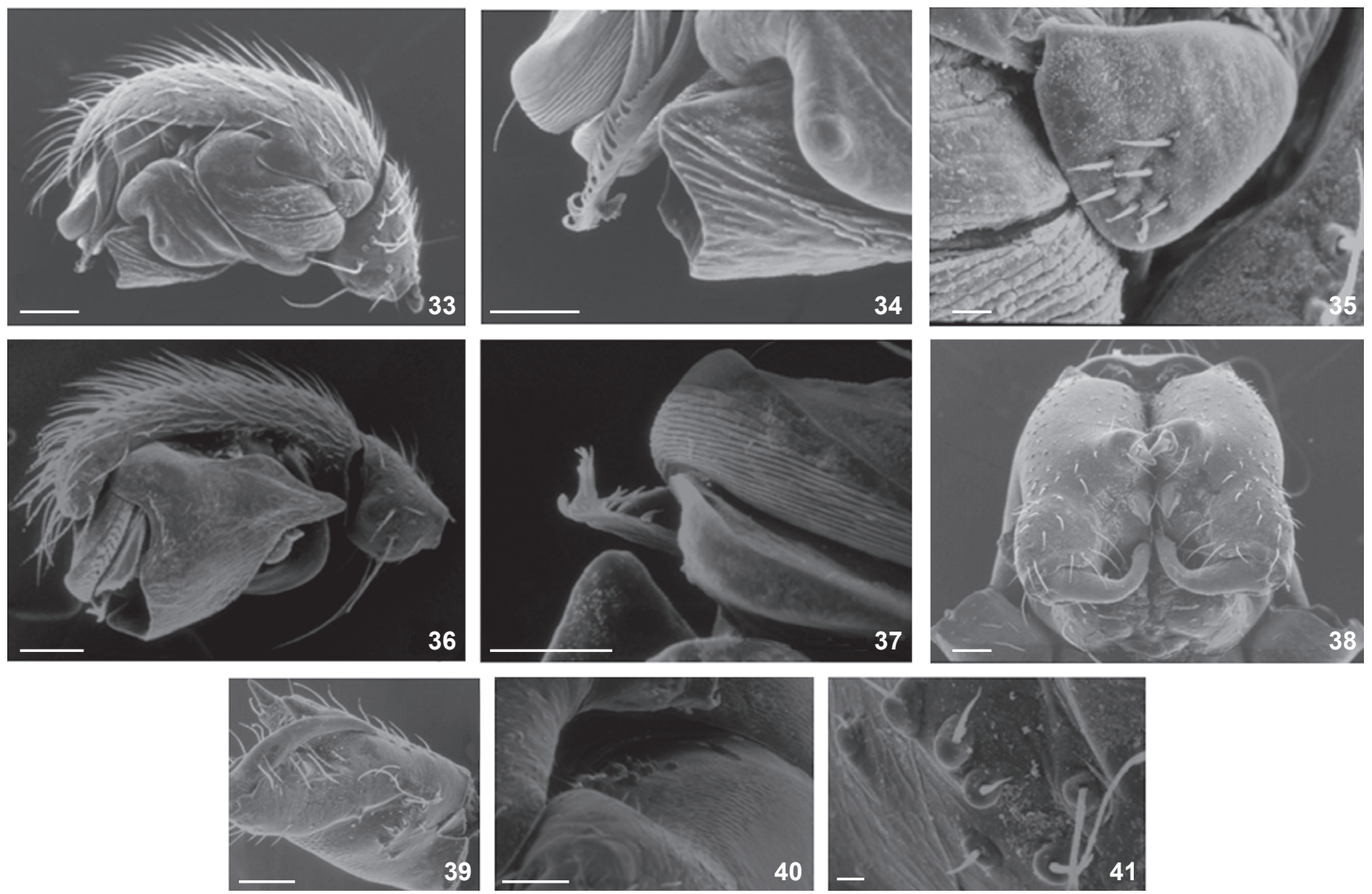

Figures 33-41. Eurymorion triunfo sp. nov.: (33-37) male palpus: (33) ectal view, (34) embolus and lamella characteristica, detail, (35) paracymbium, detail, (36) mesal view, (37) embolus and embolic membrane, detail; (38-41) male chelicerae: (38) ventral view, (39) retrolateral view, (40) retrolateral view, detail, (41) small hairs arising from tubercular basis, detail. Scale lines: (33, 36, 38 and 39$) 100$ $\mu \mathrm{m},(34,37,40) 50 \mu \mathrm{m},(35$ and 41) $10 \mu \mathrm{m}$.

median constriction (Fig. 19); dorsally whitish-yellow with black terminal area; venter and spinnerets yellow. Colulus well developed. Epiginum with long copulatory ducts and reniform spermathecae at latero-anterior position of atrium (Fig. 15).

Distribution. Known only from the type locality (Fig. 50).

Etymology. The specific name is a noun in apposition, taken from the type locality.

Natural history. Unknown.

\section{Eurymorion mourai sp. nov.}

Figs 20-21, 31, 50

Types. Holotype male from São Francisco de Paula, Rio Grande do Sul, Brazil, 19-22.III.1998, L.A. Moura leg., deposited in MCN 29183.

Diagnosis: Eurymorion mourai sp. nov. resembles E. nobile (Figs 24 and 25; Millidge, 1991: figs 238-239) by the palp having the tegulum with a distal projection and sinuous ducts, but differs in the lamella characteristica with a less prominent distal end, the embolic division with only one distal projection and the subtegulum and tegulum surpassing more than half of cymbium length (Fig. 20). The cheliceral frontal spiniform process is larger than in E. nobile and has a slightly bifurcated tip (Fig. 31).

Description. Male (MCN 29183). Total length 3.97. Carapace length 1.77 , width 0.87 , height 0.60 . Clypeus height 0.22 . Chelicerae length 0.87 , width 0.37 . Sternum length 0.87 , width 0.57. Abdomen length 1.97, width 0.70 , height 0.87 . Leg formula I/IV/II/III. Leg lengths (I/II/III/IV): femora 1.37/1.25/0.97/ 1.47; patellae 0.30/0.27/0.27/0.32; tibiae $1.32 / 1.12 / 0.77 / 1.22$; metatarsi 1.37/1.17/0.77/1.22; tarsi 0.77/0.70/0.44/0.52; total 5.13/4.51/3.22/4.75. Palp (femora, patellae, tibiae, cymbium): $0.52 / 0.12 / 0.25 / 0.60$. Position of Tm I 0.14. Metatarsi I-III with trichobothrium. The tibial spine formula: 2-2-2-2. Eye diameters and interdistances: AME 0.06, ALE 0.07, PME 0.07, PLE 0.06; AME-ALE 0.17, PME-PLE 0.13, AME-AME 0.06, PME-PME 0.15 . Anterior eye row 0.58, posterior row 0.61. Eyes (Fig. 31) with dark margins. Carapace dark red-brown, dorsally glabrous, 

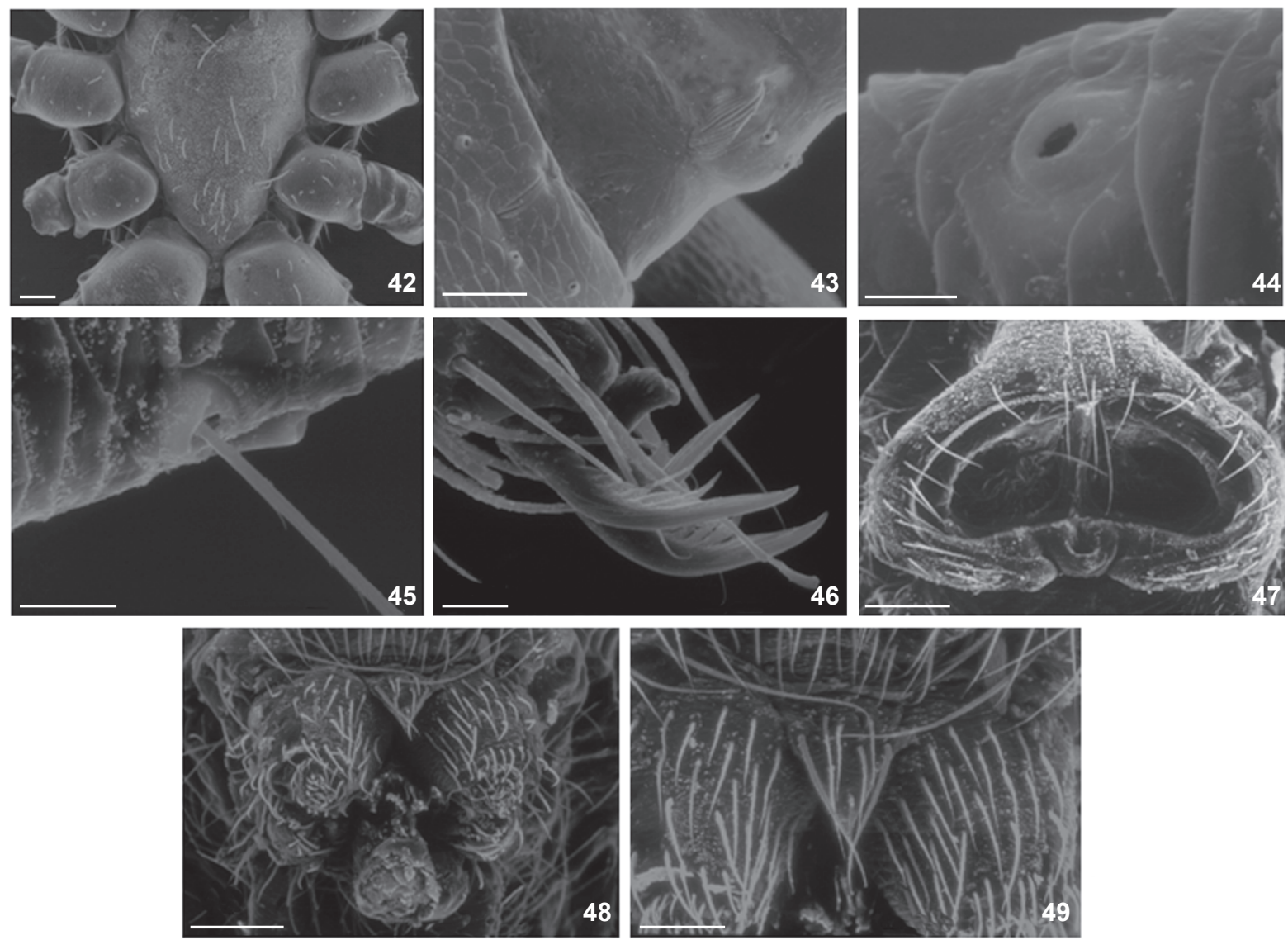

Figures 42-49. Eurymorion triunfo sp. nov.: (42-46) male: (42) cephalothorax ventral view, (43) liriform organ in coxae and trocanter III, (44) tarsal organ, leg I, (45) dorsal trichobothrium of leg I, (46) tarsal claw of leg l; (47-49) female: (47) epiginum, ventral view, (48) spinnerets, general view, (49) colulus, detail. Scale lines: (47-48) $100 \mu \mathrm{m},(42) 75 \mu \mathrm{m},(43,49) 50 \mu \mathrm{m},(45 \mathrm{and} 46) 10 \mu \mathrm{m},(44) 5 \mu \mathrm{m}$.

longer than wide, narrowing posteriorly. Chelicerae dark redbrown, well developed, with a small basal tubercle, sparse distal setae and a strong frontal spiniform process with bifurcated tip (Fig. 31); promargin with three minute teeth; retromargin with two teeth. Endites brown with dark dots. Sternum brown, densely covered by small setae, longer than wide. Coxae yellowish-brown, except III which is dark brown and smaller than the others. Legs yellowish-brown. Patellae with strong dorsal spine. Abdomen with median constriction, longer than wide; dorsally dark-brown with median unpigmented area; remarkably striated at posterior end; venter and spinnerets dark brown. Colulus well developed. Palp with elongated subtegulum (Fig. $20)$, tegulum without projection and sinuose duct and embolic division as a large mesal plate (Fig. 21).

Female. Unknown.

Distribution. Known only from the type locality (Fig. 50). Etymology. The specific name honors the entomologist Luciano de Azevedo Moura, collector of the type specimen.

Natural history. Unknown.

\section{Eurymorion insigne (Millidge, 1991) \\ Figs 22-23, 29, 50}

Eurycolon insigne Millidge, 1991: 72, figs 236-237, 240-243, holotype male, Florests da Tijuna [sic - Floresta da Tijuca] Guanabara (actual Rio de Janeiro), Brazil, deposited in AMNH, examined.

Eurynorion insigne, Platnick, 1993: 277. Platnick, 2009.

Diagnosis. The male palp of Eurymorion insigne (Figs 22 and 23; Millidge 1991: figs 236-237) differs from the male of other species in the structure of the palp, which has a less developed paracymbium and the lamella characteristica with projected tip, and in the spiniform frontal cheliceral process, which is large with a more developed base (Fig. 29).

Description. Male. Described by Millidge (1991: 72, figs 236-237, 240-243). New illustrations of the male cephalothorax in frontal view (Fig. 29) and male palp in ectal and mesal views (Figs 22 and 23) are presented based on the examination of the holotype. 


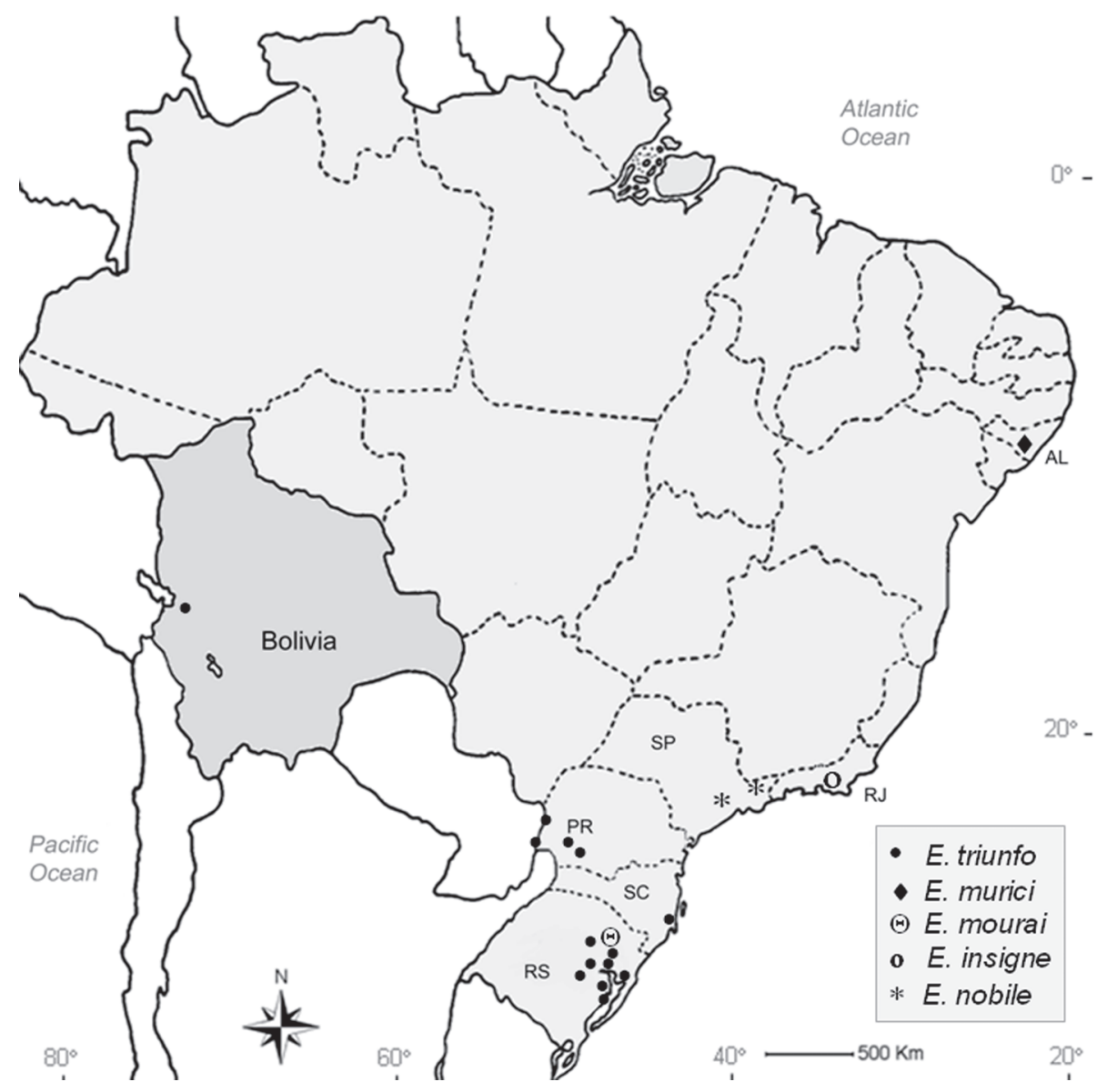

Figure 50. Map showing the distribution of Eurymorion mourai sp. nov., E. murici sp. nov., Eurymorion triunfo sp. nov., E. insigne and E. nobile in Brazil and Bolivia. (AL) state of Alagoas, (PR) Paraná, (RJ) Rio de Janeiro, (RS) Rio Grande do Sul, (SC) Santa Catarina, (SP) São Paulo.

Female. Unknown.

Material examined. Only the holotype.

Distribution. Known only from Rio de Janeiro, Brazil (Fig. 50). Natural history. Unknown.

\section{Eurymorion nobile (Millidge, 1991)}

Figs 24-28, 50

Eurycolon nobile Millidge, 1991: 72, figs 238-239, holotype male, São Jose do Barreiro, São Paulo, Brazil, 1960 m, November, 1968, M. Alvarenga leg., deposited in AMNH, examined. Eurymorion nobile, Platnick, 1993: 277. Platnick, 2009.

Diagnosis. The female epigynum de $E$. nobile resembles that of $E$. triunfo by having a large and deep atrial opening and a the ventral plate with two lateral lobes extending posteriorly, very close to each other and over the dorsal plate; it differs from that species by the presence of pair of anterior excavations on the ventral plate and the longitudinally placed spermathecae, in ventral view (Fig. 27). For a diagnosis of the male (Figs 24 and 25) see Millidge (1991: 72).
Description. Male. Described by Millidge (1991: 72, figs 238-239).

Female (MCN 20489). Total length 2.90. Carapace length 1.12 , width 0.77 , height 0.37 . Clypeus height 0.15 . Chelicerae length 0.60 , width 0.25 . Sternum length 0.65 , width 0.52 . Abdomen length 1.92, width 1.27, height 1.35. Leg formula I/IV/ II/III. Leg lengths (I/II/III/IV): femora 1.20/1.07/0.87/1.20; patellae 0.32/0.30/0.25/0.30; tibiae 1.12/0.95/0.62/0.95; metatarsi 1.07/0.97/0.67/1.07; tarsi 0.72/0.65/0.50/0.60, total 4.43/3.94/ 2.91/4.12. Palp (femora, patellae, tibiae, tarsi): 0.32/0.12/0.25/ 0.40. Position of Tm I 0.18. Metatarsi I-III with trichobothrium. Tibial spine formula: 2-2-2-2. Eye diameters and interdistances: AME 0.06, ALE 0.08, PME 0.07, PLE 0.08; AME-ALE 0.07, PMEPLE 0.06, AME-AME 0.03, PME-PME 0.11. Anterior eye row 0.43, posterior row 0.47 . Eyes with black margins, mainly AME and PME. Carapace glabrous, longer than wide, yellowish-brown with darkened margins. Chelicerae yellowish-brown, without tubercle. Promargin with five teeth, median teeth well developed, redbrown. Retromargin with five minute teeth. Endites brown with 
dark-brown dots. Sternum brown with darkened borders, longer than wide. Coxae yellowish with darkened distal borders. Legs yellow with dark-brown median and distal rings on all segments. All patellae with strong dorsal spine. Abdomen longer than wide, without median constriction, slightly prolonged after spinnerets; dorsally light yellow with two brown stripes and two lateral stripes covered with small pearl-white dots. Venter brown with irregular distributed pearl-white dots. Anterior and posterior spinnerets brown, dark stippled. Colulus well developed. Epigynum with large dorsal plate, spermathecae elongated and distant from each other, copulatory ducts long and sinuous (Figs 26 and 27).

Material examined. Brazil, São Paulo: São Miguel Arcanjo, Parque Estadual de Carlos Botelho, 1 female, 3 males, 14.X.1990, A.B. Bonaldo leg. (MCN 20489, 20492).

Distribution. Known only from São Paulo, Brazil (Fig. 50). Natural history. Unknown.

\section{DISCUSSION}

Due to their apparent morphological similarity with the new species described herein, the examination of two species described by KeYSERLING (1891) is strongly recommended. Unfortunately, the types of Linyphia armata (Keyserling, 1891) and $L$. longiceps (Keyserling, 1891), both originally described in Frontina, were not located at The Natural History Museum, London, UK, where KeYSERLING's (1891) type material was allegedly deposited.

\section{ACKNOWLEDGEMENTS}

We thank to Norman I. Platnick for the loan of the types from the AMNH. We also thank Erica H. Buckup, from the MCN, for loaning material and providing references, and to the director's office of MCN by allowing the senior author to carry out part of this work in its facilities. To Antonio D. Brescovit from the Instituto Butantan, São Paulo, for the loan of the spiders. To Janet Beccaloni (The Natural History Museum, London, UK) for the attempt to locate the types of Linyphia armata and L. longiceps. This study was supported by CNPq (process 140586/2007-5 for ENLR, Programa de Pós-Graduação em Biologia Animal da Universidade Federal do Rio Grande do Sul).

\section{LITERATURE CITED}

Keyserling, E. 1891. Die Spinnen Amerikas: Brasilianische Spinnen. Nürnberg, vol. 3, 278p.

Millidge, A.F. 1980. The erigonine spiders of North America. Part 1. Introduction and taxonomic background (Araneae: Linyphiidae). Journal of Arachnology 8: 97-107.

Millidge A.F. 1991. Further linyphiid spiders (Araneae) from South America. Bulletin of the American Museum of Natural History 205: 1-199.

Platnick, N.I. 1993. Advances in Spider Taxonomy 1998-1991. New York, New York Entomological Society, American Museum of Natural History, 846p.

Platnick, N.I. 2009. The world spider catalog, version 10.0. American Museum of Natural History. Available on line at: http://research.amnh.org/entomology/spiders/catalog/ index.html [Accessed: 10/VI/2009].

RoberTs, M.J. 1987. The spiders of Great Britan and Ireland. 2. Linyphiidae and check list. Colchester, Harley Books, 204p.

Submitted: 23.X.2009; Accepted: 30.V.2010.

Editorial responsibility: Antonio D. Brescovit 